Шостак Лілія Борисівна доктор економічних наук, професор, Університет сучасних знань, Київ, Украӥна, shostak202@ukr.net

\title{
ПЕРСПЕКТИВИ ІННОВАЦЙННОГО РОЗВИТКУ УКРАЇНИ У СВІТОВОМУ ГЛОБАЛЬНОМУ ПРОСТОРІ
}

Метою роботи $\epsilon$ висвітлення стратегії та дефініція інструментів забезпечення інноваційного розвитку економіки України під впливом глобалізаційних процесів в умовах обмеження публічних фінансів. Визначаючи пріоритетні орієнтири інноваційно-інвестиційної політики України, слід прив'язати їх до середньострокового і довгострокового економічного зростання, вписуючи їх у розстановку світових політекономічних сил і прогнозовану еволюцію світового економічного розвитку. Визначено, що в умовах обмеження публічних фінансів ефективним є створення матеріально-фінансових стимулів розвитку підприємництва у сфері інновацій. Проте найбільш вагомим чинником зростання випуску інноваційної продукції $є$ підвищення рівня технологічного прогресу за підтримки вітчизняної науки та міжнародного співробітництва в галузі новітніх технологій. Для підвищення конкурентоздатності інноваційних продуктів на глобальному ринку треба залучати дешеві фінансові ресурси для їх створення і виробництва. Реалізація наявного інноваційного потенціалу обумовлена розширенням сукупного попиту засобами фіскальної політики та інструментами зовнішньоекономічної стратегії, сфокусованої на розширенні міжнародних сегментів ринку інноваційної продукції.

Ключові слова: глобальний ринок, конкурентоздатність, інноваційна продукція, стратегія інноваційного розвитку, державний механізм управління.

Shostak Liliia, Doctor of Economics, Professor, University of Modern Knowledge, Kyiv, Ukraine Innovation development perspectives of Ukraine in the global expanse

The aim of the work is highlighting of strategies and definition of tools to ensure innovation development of Ukrainian economy under the influence of globalizationprocesses in terms of public financeslimitation. Defining priority targets of innovative investment policy of Ukraine, we should bind them to the medium-term and long-term economic growth by enrolling them in the balance of global political economy forces and predicted evolution of world economic development. It is determined that in terms of public finance limitation the creation of material and financial incentives of entrepreneurship development in the innovation sphere is effective. However, the most important factor in the growth of innovation productoutput is increasing of technological progress level, with the support of national science and international cooperation in the field of modern technologies. To increase the competitiveness of innovative products in the global market we should attract cheaper financial resources for its creation and production. Implementation of existing innovative potential is caused by the expansion of aggregate demand by means of fiscal policy and instruments of foreign economic strategy, focused on expanding of the international market segments of innovative products.

Key words: global market, competitiveness, innovative products, innovative development strategy, state management mechanism.

Шостак Лилия Борисовна, доктор экономических наук, профессор, Университет современных знаний, Киев, Украина

$\begin{aligned} & \text { Перспективы инновационного развития Украины } \\ & \text { пространстве }\end{aligned}$
в


Целью работы является освещение стратегии и дефиниция инструментов обеспечения инновационного развития экономики Украины под влиянием глобализационных процессов в условиях ограничения публичных финансов. Определяя приоритетные ориентиры инновационноинвестиционной политики Украины, следует привязать их к среднесрочному и долгосрочному экономическому росту, вписывая их в расстановку мировых политэкономических сил и прогнозируемую эволюцию мирового экономического развития. Определено, что в условиях ограничения публичных финансов эффективным является создание материально-финансовых стимулов развития предпринимательства в сфере инноваций. Однако наиболее весомым фактором роста выпуска инновационной продукции является повышение уровня технологического прогресса при поддержке отечественной науки и международного сотрудничества в области новейших технологий. Для повышения конкурентоспособности инновационных продуктов на глобальном рынке нужно привлекать дешевые финансовые ресурсы для их создания и производства. Реализация имеющегося инновационного потенциала обусловлена расширением совокупного спроса средствами фискальной политики и инструментами внешнеэкономической стратегии, сфокусированной на расширении международных сегментов рынка инновационной продукции.

Ключевые слова: глобальный рынок, конкурентоспособность, инновационная продукция, стратегия инновационного развития, государственный механизм управления.

Вступ. Інноваційний імператив соціально-економічного розвитку має визначати як перспективи добробуту населення України, так і ії позиціювання на міжнародному ринку товарів і послуг. Усталений соціально-економічний розвиток передбачає не тільки згладжування економічних циклів світової економіки, а й забезпечення певної якості життя. Впровадження новітніх технологій виробництва $\mathrm{i}$ споживання $\epsilon$ беззаперечною вимогою забезпечення подальшого економічного розвитку світової економіки та конкурентної позиції країни на глобальному ринку. Нині брак державних фінансових ресурсів, техногенні катастрофи, зношення основних та інфраструктурних фондів, відчуження і руйнування $20 \%$ території внаслідок військових дій на сході України ставлять під питання перспективи інноваційного розвитку національного господарства.

Аналіз останніх досліджень і публікацій. Нині в умовах обмежених публічних фінансів (бюджетних капіталовкладень) найбільш ефективною $\epsilon$ інноваційно-інвестиційна політика держави, спрямована на створення матеріально-фінансових стимулів розвитку підприємництва у сфері технологічних інновацій. Україна як потенційний економічний партнер має досить привабливі риси для входження транснаціональних капіталів у науково-технічний простір країни, що передбачає, з одного боку, трансмісію сучасних технологій і «ноу-хау», $з$ іншого - залучення іноземного венчурного капіталу [1]. I це, перш за все, забезпечується наявністю кваліфікованих та дешевих трудових ресурсів і науково-технічним потенціалом, здатним адаптувати новітні світові технології виробництва. Україна також має значний природно-ресурсний потенціал для розміщення капітало-ефективних високотехнологічних і ресурсномістких виробництв. Країна має виробничо-технічну базу i розвинену супутню інфраструктуру машинобудівних, хімічних, нафтопереробних галузей, здатних за умови модифікації і оновлення основних фондів до розширеного виробництва конкурентної продукції. Для залучення державних і приватних інвестицій у високотехнологічне виробництво інноваційних товарів і послуг необхідне створення стимулів для інноваційного підприємництва, серед яких ефективними залишаються наступні: економічні пільги та послаблення податкового тиску, державні гарантії, висока норма прибутку, стабільні ринки збуту [2].

Вагомим чинником зростання випуску інноваційних товарів і послуг $є$ підвищення рівня технологічного прогресу за допомогою міжнародного співробітництва в галузі новітніх технологій [3]. Стійкий ріст випуску інноваційних товарів і послуг обумовлений зростанням виробничого потенціалу, і інвестиції є не єдиним способом такого зростання через ефект пропозиції. Іншим 
важливим фактором експансії такого виробництва $є$ державні споживчі витрати, що зумовлюють підвищення сукупного попиту. Вони істотно впливають на зростання добробуту в основному за допомогою стимулювання сукупного попиту на виробничі ресурси і подальшу індукцію чинників пропозиції. Однак в Україні кейнсіанський механізм ініціації сукупного попиту через збільшення державних споживчих витрат не може бути реалізований у повній мірі. Державний бюджет України значно обтяжений зовнішніми боргами і кредитами світових фінансових структур (МВФ, Світовий банк, Європейський банк реконструкції та розвитку та ін.), які спрямовуються не на розширення та модернізацію виробництва, а на адміністративні реформи, зміцнення національної валюти і оплату боргових зобов'язань [4]. За таких умов збільшення споживчих державних витрат можливе за двома основними напрямами: (1) через дефіцит Державного бюджету (у розмірі 3-4 \% ВВП) за рахунок внутрішньої заборгованості (внутрішні позики) або за допомогою регульованої інфляції (до $15 \%$ річних).

Вагомим чинником зростання випуску інноваційних товарів і послуг $є$ підвищення рівня технологічного прогресу шляхом розширення міжнародного співробітництва в галузі новітніх технологій. Наукоємність виробництва не тільки збільшує продуктивність даного запасу капіталу та інших ресурсів, а й є важливим чинником прискорення накопичення капіталу, тобто вагома роль накопичення капіталу полягає у виконанні функції транслятора технологічного прогресу. А це означає, що фінансовий венчурний капітал має спрямовуватися на національні наукові дослідження та впровадження міжнародних розробок у виробництво.

В аргументації стійкості виробництва широко використовують концепцію «Економіки пропозиції» [5], що є однією з теоретичних основ подолання високої інфляції і супутнього ій безробіття (типове поєднання для країн пострадянської економіки). У контексті глобалізації світової економіки вона повинна бути зорієнтована на підвищення конкурентоспроможності національних товарів і послуг, тобто зниження витрат виробництва і політику протекціонізму національного виробника. Тактика економічної політики, спрямованої на стимулювання сукупної пропозиції, включає заходи, сфокусовані на стимулюванні як поточного обсягу виробництва, так і довгострокового підвищення темпів економічного зростання. До першої групи відносять заходи щодо підвищення ефективності розподілу ресурсів між конкуруючими сферами їх застосування через реформу фінансової системи, державного сектора, ринку праці та ін. Застосовуються заходи по скороченню «податкового клину» за допомогою реформи податкової системи, скорочення дотацій та ін., а також підвищення ефективності використання факторів виробництва. До другої групи відносять стимулювання заощаджень та інвестицій, інновації у сфері технологічного забезпечення виробництва i освіти, стимулювання припливу іноземних інвестицій та ін. структурні перетворення.

Мета. Визначити стратегію та інструменти забезпечення усталеного інноваційного розвитку економіки України в умовах обмеження публічних фінансів.

Постановка завдання. Вписуючи пріоритетні орієнтири інноваційно-інвестиційної політики України у розстановку світових політекономічних сил і прогнозовану еволюцію світового економічного розвитку, слід прив'язати їх до середньострокового і довгострокового економічного зростання. В основі середньострокового економічного зростання лежить реалізація наступних трьох наявних передумов:

- можливості максимального використання наявних виробничих потужностей;

- створення умов для нормальної інвестиційної діяльності;

- попередження відтоку фінансових ресурсів, отриманих у рамках національної економіки, з метою перетворення їх на головне джерело венчурного капіталу.

Загальні пріоритети стратегії довгострокового зростання і стійкості виробництва високотехнологічних товарів і послуг можуть складатися з наступного:

- адаптації важелів стимулювання інвестицій у реальний сектор економіки;

- подальшому розвитку науково-технічних інновацій, пов'язаних з ВПК і АПК; 
- впровадженні новітніх екологічно чистих технологій виробництва, транспортування та складування продукції;

- удосконаленні фіскальної і монетарної політики, спрямованих на усталене економічне зростання;

- вдосконаленні транснаціональних корпоративних відносин, орієнтованих на паритетне співробітництво.

Викладення основного матеріалу. Недосконала політика реформування у сфері освіти i фундаментальної науки може привести до такої ситуації, коли зростаюча технологічна рента стане єдиною можливістю доступу до новітніх технологій. Тому найбільш важливим пріоритетом розвитку наукомісткої економіки $є$ становлення внутрішньо захищеного фінансового сектора, який обслуговує національні інтереси інноваційного розвитку. У цьому контексті створення юрисдикцій спеціального фінансового режиму господарювання на територіях пріоритетного розвитку, у великих містах, окремих експорто-орієнтованих виробництвах, науково-виробничих територіальних структурах представляється найбільш перспективним напрямом у сфері забезпечення інноваційного розвитку (економіки знань) і зростання національного доходу. Розширення виробничого потенціалу забезпечує стійкий випуск інноваційних товарів і послуг, але інвестиції в реальний сектор є не єдиним способом такого розширення через ефект пропозиції. Іншим важливим фактором експансії такого виробництва служать державні споживчі витрати. Разом із цим при збереженні стратегічної ролі інвестицій і науково-технічного прогресу для прискорення економічного зростання в умовах обмеженості фінансових ресурсів все більшої ваги набувають проблеми оптимізації розміщення виробництва. Бюджетний дефіцит, що практикується під час кризових явищ у будь-якій економіці, не залежно від причин їх виникнення, істотно обмежує можливості уряду у сфері забезпечення інноваційної діяльності. Найбільш ефективною в умовах обмеження публічних фінансів $є$ інвестиційна політика держави, спрямована на створення матеріально-фінансових стимулів розвитку підприємництва у сфері інновацій. Залучення прямих іноземних інвестицій у реалізацію стратегічних інноваційних проектів також здатне забезпечити інноваційну діяльність нерезидентів за умови певних державних гарантій і стимулів. Значний природно-ресурсний потенціал $\epsilon$ запорукою для розміщення як капітало-ефективних високотехнологічних, так і ресурсномістких виробництв. Разом із цим, виробничо-технічна база $\mathrm{i}$ супутня інфраструктура машинобудівних, хімічних, нафтопереробних галузей потребують модифікації і оновлення, що є підставою для зміни неефективних власників основних фондів для підвищення ефективності менеджменту та стимулювання інноваційної діяльності.

Наявні передумови здатні забезпечити підстави для залучення, не тільки бюджетних асигнувань, яких у сучасних умовах недостатньо, а й приватних (національних $\mathrm{i}$ транснаціональних) інвестицій у високотехнологічне виробництво інноваційних товарів і послуг. Для активного залучення приватних капіталів в інноваційну сферу необхідне не лише створення стимулів інноваційного підприємництва для виробництва конкурентоспроможних товарів і послуг на зовнішніх ринках, а й забезпечення достатнього рівня внутрішнього сукупного попиту i купівельної спроможності населення.

Розширення інноваційного потенціалу за рахунок приватизації державних підприємств має на меті пошук ефективного менеджера, а не лише нового інноваційно-орієнтованого власника. Випуск інноваційних товарів і послуг заснований на залученні державних та приватних, у т. ч. прямих іноземних інвестицій є не єдиним способом такого розширення. Іншим важливим фактором експансії інноваційного виробництва служать державні споживчі витрати, зокрема на виробництво новітніх озброєнь вітчизняними підприємствами ВПК та авіабудування, що здатне привести до підвищення сукупного попиту. Збільшення споживчих державних витрат можливе й за допомогою регульованої інфляції (до $15 \%$ річних) 3 одночасною індексацією доходів населення, якщо мова йде про внутрішній попит на інноваційні товари і послуги.

Найбільш вагомим чинником сталого зростання випуску інноваційної продукції $\epsilon$ підвищення рівня технологічного прогресу за допомогою вітчизняної науки та міжнародного 
співробітництва в галузі новітніх технологій. Технічний прогрес $є$ визначальною умовою моделі неперервного зростання рівня життя, оскільки обумовлює стійке зростання випуску на душу населення. Якщо в кейнсіанських моделях норма збереження задавалася екзогенне і визначала величину рівноважного темпу зростання доходу, то неокласична модель Р. Солоу стверджує, що економіка прагне до відповідного стійкого рівня фондоозброєності і збалансованого зростання, якщо дохід і капітал зростають не залежно від норми заощадження. Величина норми збереження $\epsilon$ об'єктом економічної політики і важлива при оцінці різних програм економічного зростання.

В основі середньострокового економічного зростання лежить реалізація наступних трьох передумов:

- модернізація на основі впровадження результатів науково-технічних досліджень;

- державні гарантії інноваційно-інвестиційної діяльності (забезпечення високої норми прибутку венчурного капіталу);

- боротьба 3 корупцією в рамках національної економіки, що істотно підвищує трансакційні витрати національного господарства.

Необхідною i достатньою умовою соціально-економічного розвитку України $\epsilon$ середньорічне зростання валового випуску на рівні 5-7 \% ВВП [5], а за інноваційними товарами і послугами - 3-5 \% ВВП. Можливості такого зростання визначаються:

- існуванням невикористовуваних виробничих фондів (будівлі, споруди, обладнання, теплові та електричні мережі, які були недовикористані або законсервовані), велика частина яких може бути модернізована i повернута в виробництво без залучення значних обсягів капіталовкладень;

- наявністю запасів природно-сировинних ресурсів (метали, уран, золото) і супутньою інфраструктурою;

- конкурентоспроможними галузями в області літакобудування, космічних і військових технологій;

- агропромисловим потенціалом у виробництві зерна і ін. культур (соняшник, цукрові буряки, льон, ріпак, соя) на експорт;

- науково-технічним потенціалом трудових ресурсів.

Середньостроковий економічний ріст може бути здійснений у 3 етапи. На першому етапі (до трьох років) включення заморожених виробничих потужностей при високому рівні зростання форсованих інвестицій може забезпечити економічне зростання на рівні 6-7\% ВВП на рік. На другому етапі (протягом двох років) можливе зниження темпів зростання до 2-4 \% ВВП на рік через вичерпання існуючих резервів і скорочення обсягу введення нових потужностей. Ця тенденція може бути припинена $25 \%$ зростанням інвестицій у наукомісткий сектор економіки. На третьому етапі (на десятирічний період) можлива стабілізація зростання випуску інноваційних товарів і послуг на рівні вище 5 \% ВВП на рік.

Довгостроковий економічний ріст можливий тільки за умови активного державного регулювання, заснованого на визначенні секторальних пріоритетів розвитку, виробничої спеціалізації i координування ринкової політики, з розробкою державних стратегічних інвестиційно-інноваційних програм, спрямованих на зростання сукупного національного доходу. Iз цих позицій держава зацікавлена в широкомасштабних проектах розвитку інфраструктури, стратегічних ринків (зокрема й розширенні сегмента міжнародного ринку) та виконанні глобальних інвестиційних програм, в яких доходом $є$ не прямі вигоди, а створення нових робочих місць, розширення податкової бази, зростання виробництва в суміжних секторах економіки. Інвестиційні плани можуть бути складені в рамках регіональних або секторальних програм розвитку. Доступні фінансові кошти банківської системи повинні бути задіяні в інвестиційних проектах реального сектора економіки. Необхідне створення регіональних банків реконструкції та розвитку, венчурних інвестиційних фондів для середнього та малого бізнесу. У довгостроковому періоді доцільно обмеження доступу і витіснення іноземних інвесторів 3 тих секторів i виробництв, де національний товаровиробник підсилює свої позиції, має хороші перспективи для 
зростання випуску інноваційних продуктів і підвищення конкурентоспроможності національної економіки.

Основні пріоритети стратегії довгострокового зростання і стійкості виробництва високотехнологічних товарів і послуг полягають у наступному:

- адаптації інструментів стимулювання інвестицій у реальний сектор економіки;

- відродженні та подальшого розвитку науково-технічних інновацій, пов'язаних з ВПК і

АПК;

- впровадженні новітніх екологічно чистих технологій виробництва, транспортування та складування продукції;

- удосконаленні фіскальної і монетарної політики для розвитку транснаціональних корпоративних відносин, орієнтованих на паритетне співробітництво.

Вважається, що переміщення технологій у напрямку капіталу або капіталу до технологій забезпечує граничне збільшення світового випуску, проте це не свідчить про паритетне зростання добробуту націй. Країна-розробник новітніх технологій, у т. ч. у сфері банківських і страхових послуг, безумовно, підвищує рівень добробуту не тільки в результаті задоволення нових ексклюзивних потреб, а й шляхом вилучення монопольної ренти з інтелектуальної власності. Ця рента може бути знята шляхом оподаткування експортних інноваційних товарів і послуг. Нерідко максимізація технологічного рентного прибутку компанією-розробником досягається одночасним використанням цих інструментів.

Слід зазначити, що конкуренція між постачальниками технічних знань призводить до зниження технологічної ренти, тому ТНК зацікавлені в контролі нових розробок. Позитивний зв'язок присутності ТНК на технологічному ринку з швидким поширенням новітніх технологій справедливий тільки для ринку технологій розвинених країн. Зростання людського капіталу (рівень освіти, організаційних здібностей і технологічні навички) країн другого і третього світу, який поступається принципами сталого розвитку, насправді суперечить жорстким інтересам максимізації сукупного прибутку ТНК. Тому неадекватна політика реформування у сфері освіти і фундаментальної науки може призвести до такої ситуації, коли зростаюча технологічна рента стане єдиною можливістю доступу до новітніх технологій. Стратегія зняття технологічної ренти країн-реципієнтів складається з наступних позицій:

- країна-розробник зацікавлена у встановленні прав власності на технологічні знання, в той же час країна-реципієнт прагне цьому протистояти, використовуючи можливості нелегального безкоштовного використання інновацій;

- впровадження науково-технічних активів країни-розробника забезпечує поліпшення іiі торгової позиції в результаті відповідних виробничих змін;

- країна-розробник може отримувати технологічну ренту, якщо вона експортує інноваційні продукти і послуги, які дозволяють монополізувати ринок країни-реципієнта філіями ТНК, або витягує аналогічну ренту ліцензуванням технологічних удосконалень і відкриттів;

- домен ТНК прагне максимізувати технологічну ренту філій за кордоном: в разі, коли вона конкурує як продавець технологій на світовому ринку або коли країна-реципієнт некоректно оцінює альтернативні вигоди від ліцензування і впровадження технологій за допомогою філій ТНК. У цьому випадку проникнення і зростаюче технологічний вплив іноземних корпорацій на всі сторони суспільного, політичного та економічного життя менш технологічно розвиненою країни об'єктивно обумовлені нав'язаними вигодами від залучення технологічно які розвиненої країни до цінностей європейської цивілізації.

Висновки. Найбільш важливим пріоритетом розвитку наукомісткої економіки $\epsilon$ становлення внутрішньо захищеного фінансового сектора, який обслуговує національні інтереси інноваційного розвитку. У цьому контексті створення юрисдикцій спеціального фінансового режиму господарювання на територіях пріоритетного розвитку, в великих містах з відповідною науково-технологічною базою, в окремих експорто-орієнтованих виробництвах, науково- 
виробничих територіальних структурах представляється найбільш перспективним механізмом забезпечення інноваційного розвитку (економіки знань) і зростання національного доходу. Для підвищення ефективності інноваційних проектів доцільно залучати дешеві фінансові ресурси, ут. ч. орієнтовані на пайову участь у прибутку від інноваційного проекту під мінімальні або нульові відсотки (банки регіонального розвитку, венчурні фонди і навіть прямі портфельні інвестиції мусульманських банків).

Стійке зростання національного доходу можливе за умови збільшення високотехнологічного виробничого потенціалу шляхом стимулювання різних чинників пропозиції, проте таке зростання є збільшенням лише в потенційному випуску економіки. Для того щоб наявний інноваційний потенціал був реалізований, необхідне розширення сукупного попиту засобами фіскальної політики, яка генерує ендогенні джерела попиту, а також інструментами зовнішньоекономічної політики, сфокусованої на розширення міжнародних сегментів ринку (країни ШОС, СврАзЕС, певні країни Близького і Середнього Сходу та Африки). Підвищення ролі факторів попиту на внутрішньому ринку i пошук взаємовигідних зовнішніх ринків збуту високотехнологічної конкурентної продукції визначає, в кінцевому рахунку, наповнення міждержавних корпоративних зв'язків, вибір партнерів по економічній взаємодії і самі умови виживання в конкурентному просторі глобального ринку.

\section{Список використаних джерел:}

1. Геєць В. М. Суспільство, держава, економіка: феноменологія взаємодії та розвитку / В. М. Геєць ; НАН України, Ін-т екон. та прогнозування НАН України. - Київ, 2009. - 864 с.

2. Корпоративні структури в національній інноваційній системі України / за ред. Л. І. Федулової. - Київ: Вид-во УкрIНТЕІ, 2007. - 812 с.

3. Промисловий потенціал України: проблеми та перспективи структурно-інноваційних трансформації / відп. ред. Ю. В. Кіндзерський. - Київ: Ін-т економ. та прогнозування, 2007. $408 \mathrm{c}$.

4. Статистичні матеріали щодо державного та гарантованого державою боргу України [Електронний ресурс]. - Режим доступу: www.minfin.gov.ua/.../statystychni-materialy-shchododerzhavnoho-ta-harantovanoh. - Назва з екрану. - Дата звернення 25.02.2017.

5. Теорії «економіки пропозиції» та «раціональних очікувань» [Електронний ресурс]. Режим

доступу: http://pidruchniki.com/1366010237891/politekonomiya/teoriyi_ekonomiki_propozitsiyi_ratsionalnih_och ikuvan. - Назва з екрану. - Дата звернення 25.02.2017.

6. Шостак Л. Б. Усталеність економічного зростання в рамках соціо-екологічних обмежень / Л. Б. Шостак // Економіка природокористування і охорони довкілля. - Київ: РВПС України НАН України. - 2001. - С. 35-44.

7. Шостак Л. Б. Макроекономічне моделювання сталого економічного зростання у сучасних умовах / Л. Б. Шостак // Теоретичні основи и стратегія глобального сталого розвитку: матеріали міжнар. наук. симп. - Санкт-Петербург, 2013.

8. Шостак Л. Б. Инвестиционная политика в условиях бюджетного дефицита / Л. Б. Шостак // Стратегії інноваціонного розвитку економіки: монографія / Л. Б. Шостак. - Харків: НТУ «ХПІ», 2013. - Ч. 2. - C. 247-268.

\section{References:}

1. Heiets, V.M. (2009). Society, state, economics: phenomenology of interaction and development. Kyiv: National Academy of Sciences of Ukraine; National Academy of Sciences of Ukraine Institute for Economics and Forecasting.

2. Fedulova, L.I. ed. (2007). Corporate structures in the national innovation system of Ukraine. Kyiv: UkrINTEI Publishing. 
3. Kindzerskyi, Yu.V. ed. (2007). Industrial potential of Ukraine: problems and perspectives of structural and innovation transformation. Kyiv: National Academy of Sciences of Ukraine Institute for Economics and Forecasting.

4. Statistical materials on the state and guaranteed debt of Ukraine. [online] Availiable at: www.minfin.gov.ua/.../statystychni-materialy-shchodo-derzhavnoho-ta-harantovanoh. [Accessed 25 February 2017]. Title from the screen.

5. Theories of "supply economics" and "rational expectations". [online]. Available at: http://pidruchniki.com/1366010237891/politekonomiya/teoriyi_ekonomiki_propozitsiyi_ratsionalnih_och ikuvan. [Accessed 25 February 2017]. Title from the screen.

6. Shostak, L.B. (2001). The sustainability of economic growth within social and environmental constraints. Ekonomika pryrodokorystuvannia y okhorony dovkillia [Environmental economics and environmental protection]. Kyiv: RVPS of Ukraine of the National Academy of Sciences of Ukraine, pp. $35-44$.

7. Shostak, L.B. (2013). Macroeconomic modeling of sustainable economic growth in modern conditions. Theoretical Foundations and Strategy of Global Sustainable Development: Materials International scientific symposium, St. Petersburg.

8. Shostak, L.B. (2013). Investment policy in conditions of budget deficit. Strategy of innovation and development of economy: monography. Kharkiv: NTU «KhPI», Part 2, pp. 247-268.

(C) Шостак Л. Б., 2018 